POLITYKA ENERGETYCZNA - ENERGY POLICY JOURNAL

$2021 \star$ Volume $24 \uparrow$ Issue $4 \uparrow 139-152$

DOI: $10.33223 / \mathrm{epj} / 144907$

Iryna NyENNO ${ }^{1}$, Vyacheslav TRUBA ${ }^{2}$, Iryna LOMACHYNSKA ${ }^{3}$, Olena MAZUR $^{4}$

\title{
Digital public goods as a means to support affordable and clean energy
}

ABSTRACT: The importance of increasing the level of renewable energy sources is connected with the fact that its share in the total volume of energy consumption is still insufficient. This is why this article focuses on the development of the motivation system aimed at the more active transition to renewable sources consumption in the balanced combination alongside the traditional sources. The research question is whether digital public goods (DPG) may be a mean to support "Affordable and Clean Energy" use. The theoretical approach to our research problem is stakeholder's theory, while the concept applied to the motivation mechanism implementation is the United Nations Organization's concept of sustainable development goals (SDG). The research design is as follows: study of the actual data of energy structure of the world economy; identification of the current instruments of renewable energy distribution; analysis of the DPG as a perspective form of the sustainable energy behavior introduced [AO1] in the digitalized environment; definition of the energy industry

$\triangle$ Corresponding Author: Iryna Nyenno; e-mail: inyenno@onu.edu.ua

1 Management and Innovations, Odessa I.I Mechnikov National University, Ukraine; ORCID iD: 0000-0003-0762-808X; e-mail: inyenno@onu.edu.ua

2 Civil and Law Disciplines, Odessa I.I. Mechnikov National University, Ukraine; ORCID iD: 0000-0001-7782-2166; e-mail: truba-v@ukr.net

3 Economics and Entrepreneurship, Odessa I.I. Mechnikov National University, Ukraine; ORCID iD: 0000-0002-6112-6884; e-mail: i.lomachynska@onu.edu.ua

4 Management and Innovations, Odessa I.I Mechnikov National University, Ukraine; ORCID iD: 0000-0002-4540-9761; e-mail: mazurelena13@gmail.com

2021. The Author(s). This is an open-access article distributed under the terms of the Creative Commons Attribution-ShareAlike International License (CC BY-SA 4.0, http://creativecommons.org/licenses/by-sa/4.0/), which permits use, distribution, and reproduction in any medium, provided that the Article is properly cited. 
stakeholders; development of the architecture of energy consumption by DPG application to reach SDG "Affordable and Clean Energy". The main findings of the study are that DPG has been found to be a relevant means for the motivation and support of sustainable energy behavior through the architecture of energy consumption, based on research and development, customer relationship management, corporate social responsibility - sustainable development, technical implementation, and the diversity of traditional and alternative sources of energy.

KeYwORDS: energy, system, digital public goods, sustainable development goal, value

\section{Introduction}

The energy consumption prospective, climate risks influence, negative environmental impact, exhaustion of natural resources and new digital landscape of the economic development have caused new viewpoints to emerge. They are based on new determinants and particularly on the re-examination of the incentives of energy industry stakeholders. Numerous attempts to support sustainable energy behavior using different forms (from sanctions and penalties to bonuses and premiums) and strategies (from control attributes to the voluntary participation of people) exacerbate a necessity for finding the way to the reach sustainable development goals (SDG) of the United Nations (UN). Specifically, we consider reaching such a goal as "Affordable and Clean Energy", possible in the case of the stakeholders' motivation for sustainable energy behavior implementation.

Thus, the aim of this study is to develop a motivation mechanism in order for all the stakeholders of energy consumption to reach the SDG "Affordable and Clean Energy" by means of digital public goods (DPG) introduced in the energy industry. The possibility to meet the stakeholders' expectations is a cornerstone of the energy system. The DPG plays the role of a certain barometer to become the tool for the introduction of sustainable energy behavior. It may play a crucial role in progress evaluation of the energy saving approach and in the possible increase of customers' loyalty. Thus, the main problem of the study is to identify incentives for creating the motivation mechanism for successful implementation of the transition to the renewable energy sources. The key performance indicator of this mechanism will be the use of the different sources of energy, based on their optimal combination with the aim of energy consumption reduction. 


\section{The digital public goods approach for sustainable behavior in energy consumption}

The human factor and motivation plays a key role in creating the sustainable energy system. The final output of building this kind of system is the possibility to engage the complete range of energy system actors - individuals, households, companies and organizations are included. The essence of the motivation may demonstrate whether sustainable energy positively impacts the quality of human life. This is a factor for achieving sustainable development goals such as affordable and clean energy (Steg et al. 2021). The complete involvement of the different groups of stakeholders requires the incorporation of various motivational incentives, namely norms, attitudes, values and preferences. Their pro-environmental action is based on altruistic behavior foundations. This means that people would support public policy in cases in which the public decision-making process appreciates their values and interests. They are motivated to support energy efficiency if they feel they are influential, involved and interactive with regard to the incorporation of these values. Such an interaction of public and political or governmental support of sustainable energy behavior may take place in the framework of promoting the concept of digital public goods.

In 2019, the UN Secretary-General introduced the definition of digital public goods (Digital Public Goods Alliance), the standard of which is "open source software, open data, open license models, open standards and open content that meets confidentiality and other best practices, does not cause harm and is extremely important for achieving the UN Sustainable Development Goals by 2030". This definition is contained in the Roadmap for Digital Cooperation until 2020, and forms the basis of the register of digital public goods.

The seventh sustainable development goal "Affordable and Clean Energy" is presented by twenty-three nominees and two approved digital public goods. Among the nominees there are a real-time visualization of the $\mathrm{CO}_{2}$ emissions of electricity consumption and the Open Source Energy Management System Open EMS. Open-source software and system solution that provides unified and secure data exchange between organizations "X-Road" and "OpenG2P", which stands for "open government to person payments and provides the tools needed to digitize large scale cash transfers with open source building blocks", are recognized as the digital public goods for this UN goal (Digital Public Goods Alliance).

According to the United Nations Roadmap (Yin et al. 2021), the tools to achieve the goals of sustainable development are:

$\checkmark$ digital public goods platforms that distribute them, attract talent and accumulate data;

$\downarrow$ promoting relevant human rights and governance frameworks for such benefits;

४ supporting digital public goods, including by increasing investment, supporting efforts and strengthening coordination;

$\checkmark$ deploying digital public goods as part of their immediate response and approach to achieving sustainable development goals. 
Current trends in the impact of the fourth industrial revolution require the identification of trends and the results of digitization processes. The study has shown that public funding of research and education based on public goods is effective if the interests of politicians and society are reconciled. Taking into account the expectations of the private sector from science, it should be based on hybrid forms of management and investment, one of which is the holding of a corporate structure. At the same time, the synergy of the international community in striving to achieve the goals of sustainable development has led to the concept of "digital public goods", which is the basis for the development of scientific and technological thought in the context of digitalization.

DPG may be a means to pushing energy saving living based on the environmental progress and decrease of energy consumption. This prospect should be obligatorily widespread within energy system stakeholders as a mechanism with practical implications. It must visualize the energy security issues and the direct impact of human energy behavior on the achievements of the sustainable development goal of the United Nations: Affordable and Clean Energy (Goal 7).

For this purpose, the digital infrastructure should include: architecture for connections; specialized software to promote digital interactions; platforms for facilitating the introduction of digital public goods as a certain modern utility; big data storage for individual data accumulation; potential evolution of the digital public good output with the interaction of artificial intelligence (Gurumurthy and Chami 2019).

Digital public goods are seen as an open access solution in a technically equipped world. Thus, the emergence of the digital public good requires investment in affordable software, open data and artificial intelligence.

Such an approach should be based on a special system, created as a tool for urban and country planning. Thus, digital public goods would become a form of engagement technologies to accelerate and simplify the process of the achievement of sustainable goals in energy policy. In order to engage stakeholders, the five stages of the model of public participation developed by the International Association for Public Participation can be used. They are the actions to: inform, consult, involve, collaborate and empower. Estefam (2021) suggests the appropriate tools for these stages:

1. Informing stage - sms, digital pop-ups, chatbots, videos, websites, emails, webinars, virtual reality, online open house, augmented reality, open data.

2. Consult - sms, chatbots, focus groups, workshops, digital platforms, whiteboard, live online meetings.

3. Collaboration - collaborative documents, mappings, gamification, budget simulation.

4. Empower - gamification, crowd-sourcing, hackathon.

However, the higher levels require a wide range of digital knowledge as well as suitability to the social values of the community. In the study of Wiser (Wiser et al. 1997), renewable energy presents a mix of private and public goods benefits. Certain features of renewable energy are described as having public benefits, namely environmental, intellectual property and the possibility to share risks among the private producers. Thus, we consider it possible to attract the citizens for sustainable energy behavior. The roles of citizens are assumed to be initiator, co-designer and 
implementer (Jarke 2020). From another other point of view, we could say the roles are explorer, idea former, designer and diffuser. In this sense, the government may meet such goals required to guide the empirical collaboration with citizens, such as the sharing of control, the sharing of live expertise, and enabling individual and social changes.

Is it is clear from the chart that the share of the renewable source consumption from 1965 to 2020 remains low (see Fig. 1).

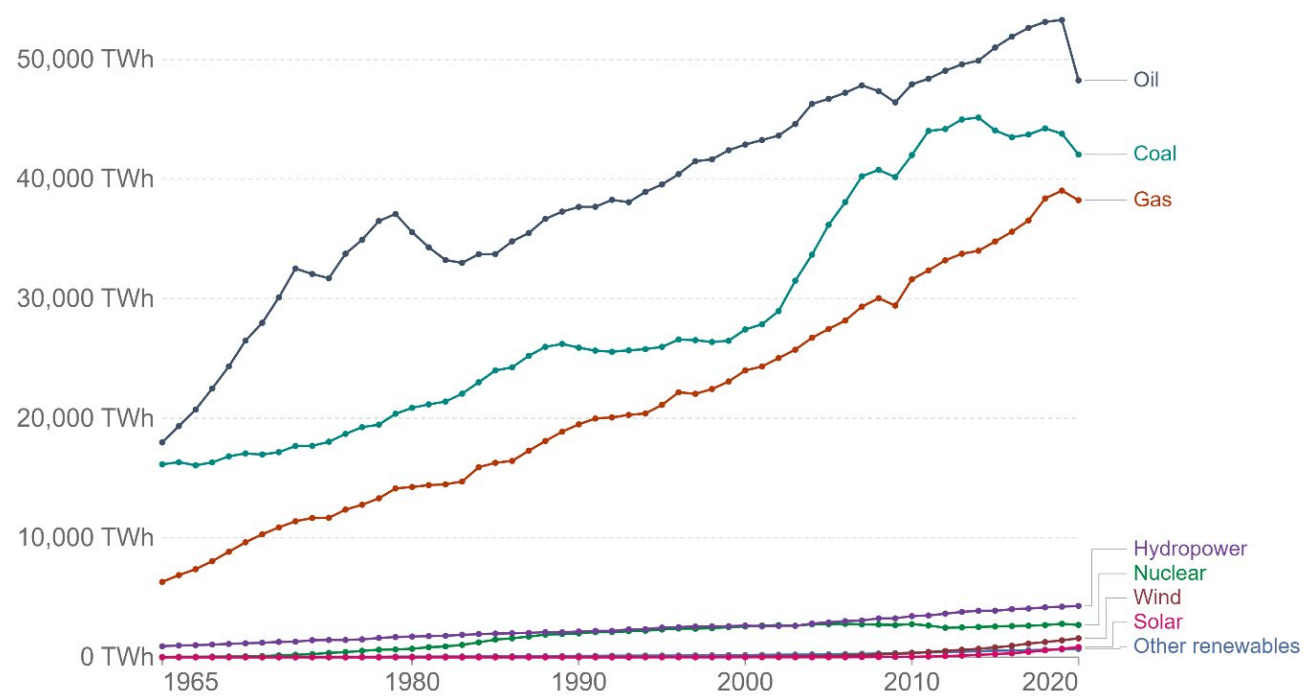

Fig. 1. Primary direct energy consumption by source, 1965-2019

Source: our world in data https://ourworldindata.org/grapher/primary-energy-consumption-by-source

Rys. 1. Bezpośrednie zużycie energii pierwotnej według źródeł w latach 1965 - 2019

Let's consider the positive experience of Norway (Ikiz 2019), where the share of primary energy in renewable sources is evaluated as the one producing the highest level of electricity. Norwegian electricity production is mainly based on hydropower with the share of wind and thermal power being less than $3.5 \%$. The diversification of the energy supply sources in Norway caused the successful case of energy security in terms of energy supply. Moreover, Norway's energy production volume is higher than its domestic demand, thus Norway is a source of energy security to other countries and provides storage facilities. The public participation may be described as well by the energy taxation system, where energy tax is used for environmental issues; some industries are exempted from electricity tax and mineral oil tax budget is a hedging fund to protect against changes in prices for petroleum. Research and development in Norway are aimed at reaching the energy efficiency country model. To introduce the enhancement in flexible heating, renewable energy consumption and production, promoting environmentally friendly producers and energy efficient buildings support the new technological environment, based on the platform of secure energy supply may be implemented. 
From the macroeconomic perspective, the influence of the digital forms of public goods is possible only in the case of the availability of certain channels to implement it in the reality of the energy consumption process for all the groups of energy stakeholders (see Fig. 2).

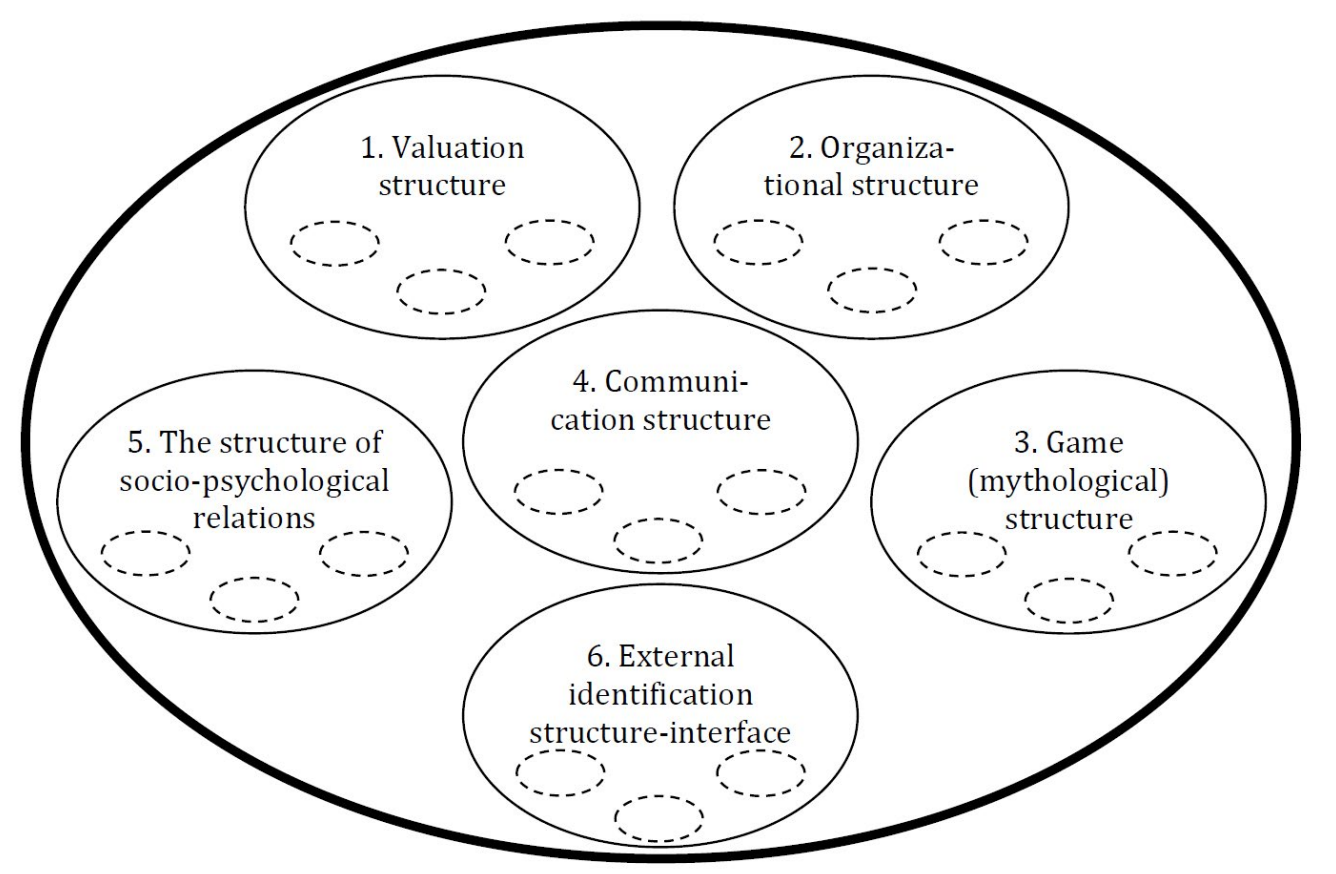

Fig. 2. Stakeholder Management Framework for the DPG - Prosumer Source: own development

Rys. 2. Ramy zarządzania interesariuszami dla cyfrowych dóbr publicznych - Prosumenci

From the stakeholder's perspective, such an influence may arise as a sequence of the transition of the consumer role to the so-called prosumer. The prosumer in this case becomes involved in the design, manufacture, or development of such a product or service as digital public goods. In this sense, the prosumer will simultaneously produce and develop the DPG. The increasing number of prosumers will bring the perspective of meeting to the valuation structure (stage 1) and subsequently meeting the organizational structure (stage 2 for the legal entities); appropriate mythological structure (stage 3 ) of certain mentality or corporate culture; concern with the existing communication structure (stage 4); multiplication of the number of prosumers of the DPG because of the scrutinizing of the socio-psychological relations (stage 5); link to the DPG interface in order to externally manifest the multiple advantages of the energy saving sustainable behavior for the consumers (prosumers). This kind of holistic approach covers the relevant perceptions of DPG by all the groups of stakeholders. It transforms the consumers' role to the relevant form of prosumer's impact and increase their motivation to balance different energy sources and also to 
save energy. The underlying ideas are to develop the system for energy consumption in the form of digital public goods aimed at eliminating the gap between the different groups of stakeholders by obtaining the picture of incentives or attitude-like judgements through the web environment of the energy prosumer (see Fig. 3).

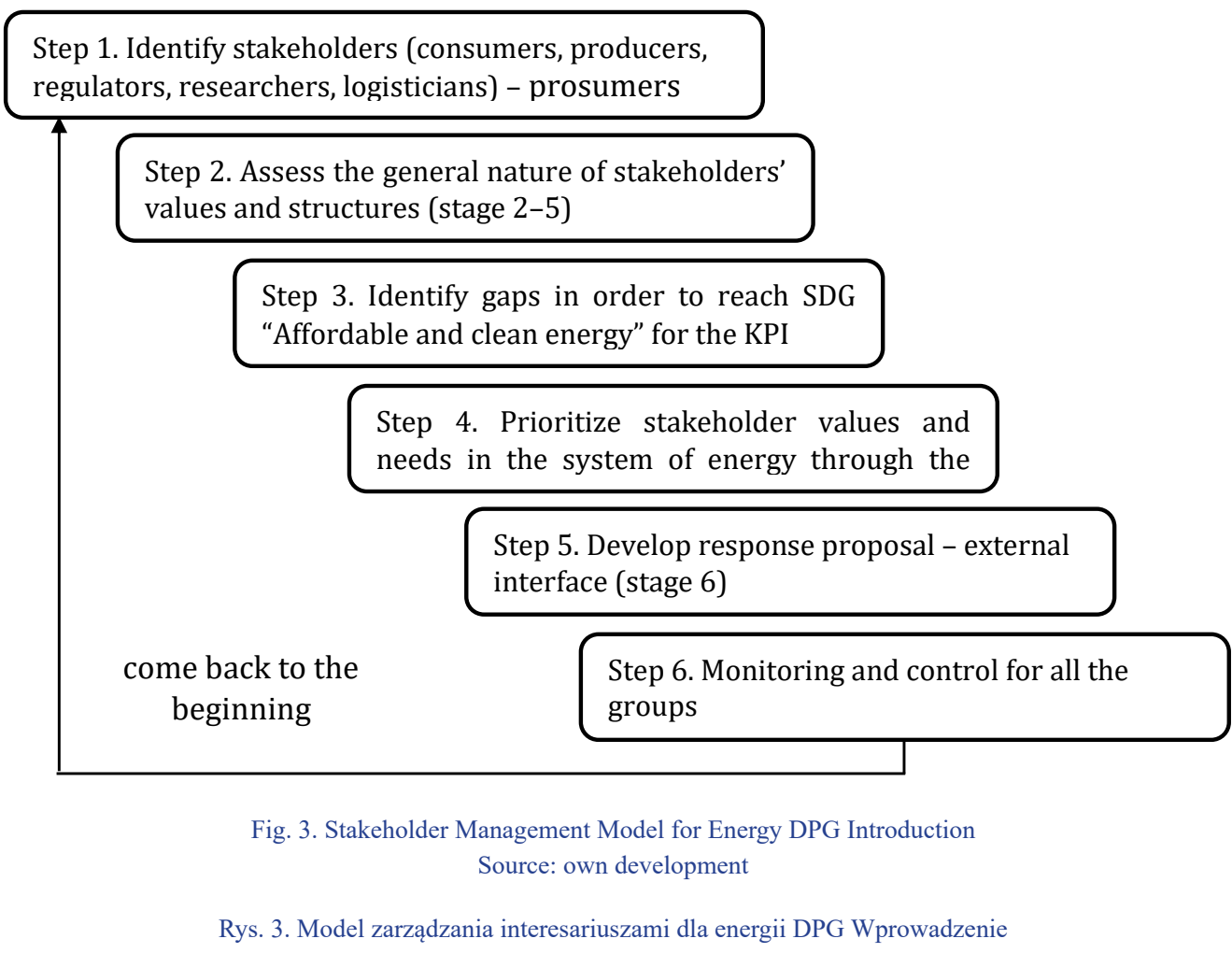

The methodology to introduce the DPG "Affordable and Clean Energy" framework as a practical mechanism to transform energy industry consumers to prosumers.

\section{System for energy consumption by digital public goods}

The non-rivalry and non-excludability of energy as a public good is a way to introduce its full potential through digital form (Saebo 2021). This is a way to attain the sustainable development goal because of the relatively easy circulation of the digital technology across time and space in comparison with machinery. This allows the organization of stakeholders' networking with the implementation on digital platforms. The DPG in this system is a tool 
which possesses generativity to the customers and may provide the global scale of use. The concept of the system of sustainable energy behavior by the means of digital public goods is presented below (see Fig. 4).

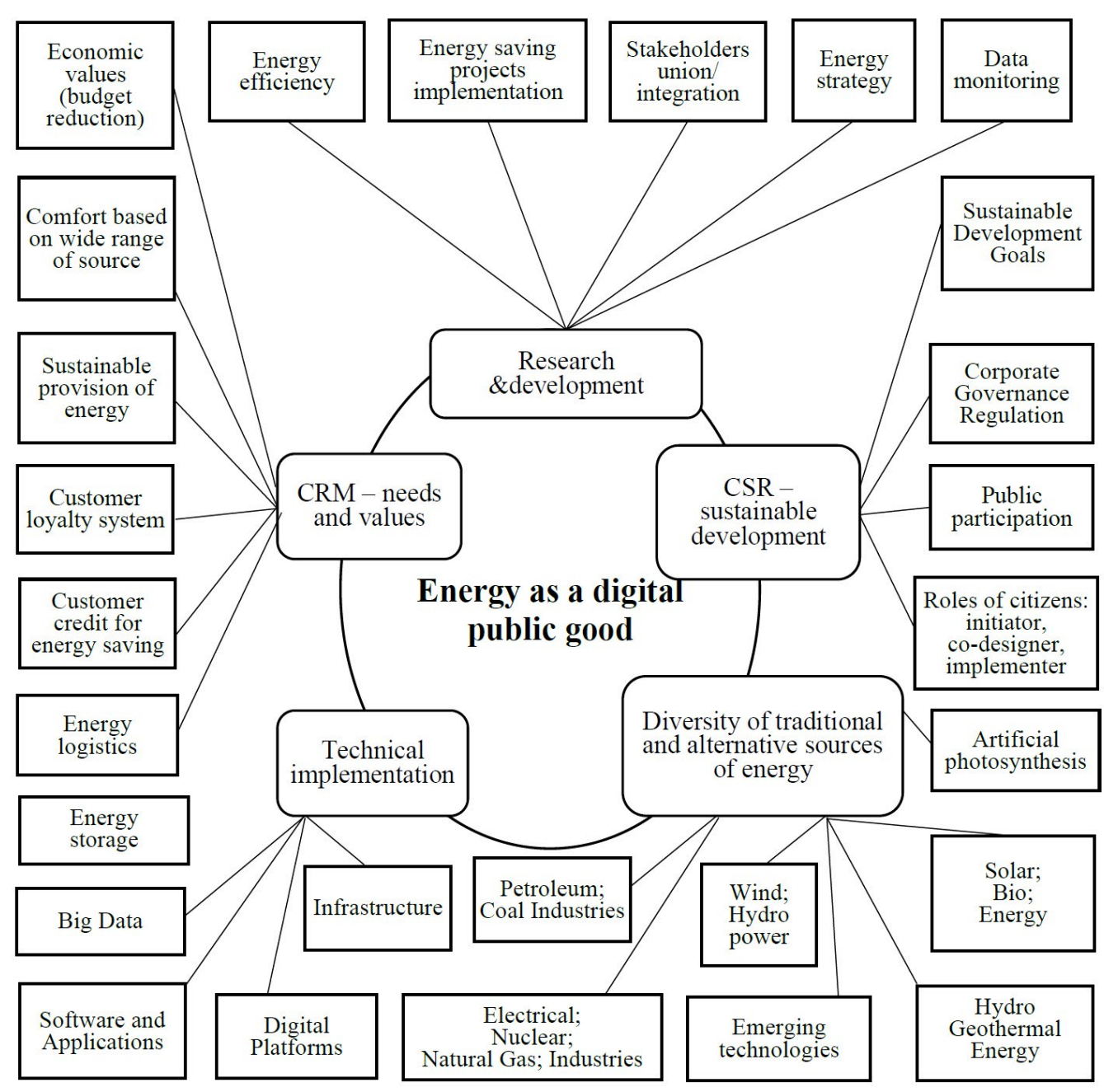

Fig. 4. Architecture of sustainable energy behavior introduction by means of DPG Source: own development

Rys. 4. Wprowadzenie do architektury zrównoważonych zachowań energetycznych z wykorzystaniem cyfrowych dóbr publicznych

Research and development process in the system of energy as a digital public good may be introduced through a certain model of customers' participation, based on the identification of their needs and values. Such an engagement may be initiated on the educational stage when local Uni- 
versities present certain strong educational and research programs in collaboration with ministries or other governmental bodies liable for Energy Policy, Digitalization. The design of the parameters of the organization of the Virtual Learning Factories (HEIN 2021) is aimed at: achieving basic competencies in the integrity of thinking; the ability to adapt the behavior of organizations; the ability to cooperate and achieve interdisciplinary results, reduce gaps between information flows and learn quickly; the ability to interact with a variety of new interfaces; communication and transforming ideas into concrete projects; creative and digitalization skills; the ability to access and use knowledge of domains (methodologies, languages, tools) for a specific job or task; organization; the ability to communicate and form stable social connections, including the help of artificial intelligence; the ability to perform highly intellectual activity; programming skills and IT knowledge; deep understanding of the relationships between electrical, mechanical and computer components; thinking at the organizational level (Eberhard et al. 2015; Sackey 2017).

The implementation of digital technologies into the educational progress may be based on the manual "Boosting Virtual Reality (VR) Learning within Higher Business Management Education" (VR Insight 2020). It presents technologies for teachers that allow them to build their own world and invite students to it in order to interact together in the space they choose. The materials of the training depend on the content created by users or trainers, where they can customize the VR/world environment and their own avatars, objects, etc.).

The technical implementation should be based on: architecture and the big data concept of Industry 4.0; developed special software and applications; digital platforms creation. The interface of the platform appropriately must help to fit the customers' needs to the final KPI of the energy saving approach. Customers' values as a variety of incentives should include their economic values as a possibility to reduce their costs for energy consumption; the occurrence of comfort, grounded on the options of the variety of energy sources' use, both alternative and traditional; their security, fixed by the sustainable energy provision; participation in the customers' loyalty system; availability of the customers credits for the energy saving outputs; implementation of energy logistics as the way to organize customer infrastructure from one side, and digital architecture, from the other side.

The main criticism and even the risk of DPG is present in the way that public goods and digital public goods may not possess equality in the sense of non-rivalry and non-excludability (Greenstein 2015). Technical knowledge and the digital technologies themselves constantly need effort and investment in research. Moreover, the sustainability of the system is dependent not only on the legal framework, controlled by the government but also on the private standardization initiatives regarding the digitalization of web-processes. The development of these standards is still in progress but is supported, for example, by the W3C - World Wide Web Consortium. Thus, digital public goods increase the level of sustainable energy behavior. This is the way the DPG will play the role of leverage for energy saving solutions and the achievement of sustainable goals (Udayasankaran et al. 2021).

Securing the provision of sustainable energy is not only the ability to make the supply appropriate to the energy demand but also the environmental protection of the world (Szalbierz 2017). The multidimensional evaluation of energy security as well as the dispersion of this func- 
tion among the undefined actors may lead to an unreliable supply of energy and disruptions in energy transmission. The most ambitious goal in the provision of energy security is the same: building a networking platform, based on the consumers' behavior, specifically creating incentives to follow the sustainable energy behavior. The solution lies in the development of intelligent networks for digitalization.

Nevertheless, the energy security concept does not completely cover human security, although there is a clear link to energy as a public good for the secure life of all human beings' (Karlsson-Vinkhuyzen et al. 2013). Human security is supported by food, health and economic security, while energy security may contradict environmental security, personal and community security because of the potential harm. This is the reason why public energy governance is needed to provide the regulation for the stakeholders' cooperation in the energy industry for energy production and consumption as a fundamental basis for sustainable development (see Fig. 5).

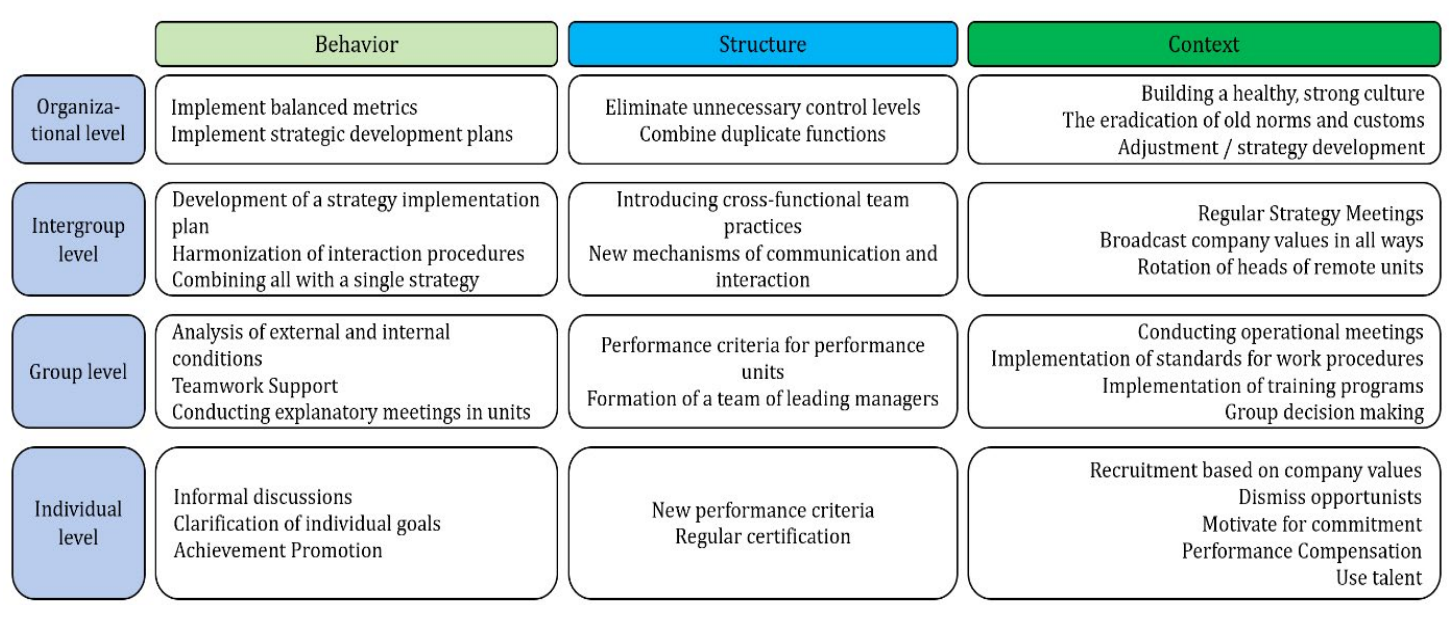

\author{
Fig. 5. Stakeholder Management Model \\ Source: own development \\ Rys. 5. Model zarządzania interesariuszami
}

A stakeholder management model should be implemented according to the values, introduced in behaviors, structure and context of each customer. The methodology to introduce this framework is delivered through the six steps necessary to implement the six stages of the stakeholder management framework for transforming the consumers of the energy industry to prosumers (Norouzi 2020).

Certain researchers (Chan and Kotchen 2014) confirmed that the possibility to introduce new technologies depends on the output which should be complementary or substitute itself in consumption. In their research, Hulsof and Mudler (Hulsof and Mulder 2020) showed that there was no connection between corporate social responsibility and higher profits, as well as between 
the renewable energy consumption itself and the higher profit effect occurrence. This means that the system of energy as a DPG should not be based on the willingness to pay for renewable energy but on organizing a model of public participation and governmental regulation which is aligned with the company profit maximization objective. The presented investigation contributes towards a better understanding of the influence of a digital public goods system on the energy consumption to implement an energy saving approach and sustainable energy behavior. The system of energy, described in the present research, provided by the means of DPG enabled the accumulation of the values of different groups of energy industry stakeholders and assimilation of their values as a composition of valuation, organizational, mythological, communication and socio-psychological structures in an external identification structure or digital interface. The system covers R\&D, CRM, CSR and technical implementation direction, based on the diversity of traditional and alternative sources of energy. Participation of the stakeholders in consumption by a means of DPG allows the introduction of a collaborative approach on the basis of their role as prosumers. The doctrine of a participative approach for the multiplication of energy sustainable behavior will become a protective barrier against the negative perception of the energy industry stakeholders.

\section{Conclusions and discussion}

The increase of the share of renewable energy in the total volume of energy consumption, as well as general reduction of energy consumption, is a way to save our planet from pollution. As it was shown in the study, to reach this goal, energy industry stakeholders' motivation is a factor of crucial impact. Motivation is the main mechanism to bring all the energy stakeholders together and to transform energy consumers to energy prosumers, involved in DPG spread. Use of the DPG, which is a tool suggested by the UN to reach the SDG "Affordable and Clean Energy" was clearly identified as being a possible strategy to reach this goal. As the study showed, DPG will lead to energy sustainable behavior in combination with the architecture of energy industry consumption. If we cannot bring the motivation mechanism as an incentive for sustainable energy behavior, our calls will surely not change consumers' attitudes.

The successful case of Norway's energy supply diversification was analyzed as one of the best examples of a country's energy efficiency model. Its research led to the conclusion that the efficient model is based on the energy stakeholders' management, where the consumers plays an important role. The study proposed a stakeholders' management model, designed for behavior, structure and context on individual, group, intergroup and organizational levels. The model should motivate sustainable energy behavior. For this purpose, the study indicates the architecture, including the mean of DPG. The architecture of sustainable energy behavior introduction covers R\&D, CRM, CSR, technical implementation and all the diversity of the energy sources. Each element is linked to the appropriate stakeholders' goals and activities. 
More research and innovation are necessary to share the idea of the necessity to provide the SDG "Affordable and Clean Energy" in the context of digitalization. The limitations of the investigation lie in the fact that we have not studied the practical contribution of the developers of energy DPG. Future lines of research may be developed in the sense of better tailoring to the energy policy of different countries.

\section{References}

Boosting Virtual Reality Learning within Higher Business Management Education. [Online] http://www. vrinsight.org [Accessed: 2021-09-07].

ChAn, N.W. and Kotchen, M.J. 2014. A generalized impure public good and linear characteristics model of green consumption. Resource and Energy Economics 37, pp. 1-16, DOI: 10.1016/j.reseneeco.2014.04.001.

Digital Public Goods Definition - Official web-site Digital Public Goods Alliance. [Online] https://digitalpublicgoods.net/registry/ [Accessed: 2021-09-07].

Eberhard, A. et al. 2015 - Eberhard, A., Metternich, J., Tisch, M., Chryssolouris, G., Sihn, W., ElMaraghy, H., Hummel, V. and Ranz, F. 2015. Learning Factories for Research, Education, and Training. Procedia CIRP 32, pp. 1-6.

Estefam, A. 2021. Strategic overview of digital public participation tools for urban planning. Journal of Science-Informed Design, DOI: 10.33797/SIDE.21.008.

Greenstein, S. 2013. Digital Public Goods. IEEE 33(5), pp. 62-63, DOI: 10.1109/MM.2013.96.

Gurumurthy, A. and Chami, N. 2019. Digital Public Goods: A Precondition for Realising SDGs. Global Governance Spotlight 4, pp. 1-5. [Online] https://www.researchgate.net/publication/343547426_Digital_Public_Goods_A_Precondition_for_Realising_SDGs [Accessed: 2021-09-07].

HEIn4 2021. Boosting the role of HEIs in the industrial transformation towards the Industry 4.0 paradigm in Georgia and Ukraine. [Online] http://www.hein4.net [Accessed: 2021-09-02].

Hulshof, D. and Mulder, M. 2020. The impact of renewable energy use on firm profit. Energy Economics 92, Article 104957, DOI: 10.1016/j.eneco.2020.104957.

İkiz, A. Ed. 2019. Energy Economics. Economic dynamics of global energy geopolitics. Hershey PA, USA, IGI Global Engineering Science Reference, 333 p. [Online] https://www.researchgate.net/publication/337198803_Energy_Economics [Accessed: 2021-09-07].

JArke, J. 2021. Co-Creating Digital Public Services. [In:] Co-creating Digital Public Services for an Ageing Society. Public Administration and Information Technology 6, pp. 15-52. Springer, Cham, DOI: 10.1007/978-3-030-52873-7_3.

KarlSSON-VinkhuYZen, S.I. and Jollands, N. 2013. Human security and energy security: a sustainable energy system as a public good. [In:] H. Dyer and M.J. Trombetta (Eds.), International Handbook of Energy Security 23, pp. 507-526, Edward Elgar Publishing, DOI: 10.4337/ 9781781007907.00036.

Norouzi, N. and Norouzi, M. 2020. Energy Analysis Framework. An Introduction to the Energy Economics. Scholars' Press, 391 p. [Online] https:/www.researchgate.net/publication/342393402_An_Introduction_to_the_Energy_Economics [Accessed: 2021-09-21].

SACKey, S. et al. 2017 - SACKey, S., BeSter, A. and AdAms, D. 2017. Industry 4.0 Learning Factory Didactic Design Parameters for Industrial Engineering Education in South Africa. South Africa Journal for Industrial Engineering 28(1), pp. 114-124. 
SÆвØ, J.I. et al. 2021 - SÆвØ, J.I., Nicholson, B., NielSen, P. and SAhay, S. 2021. Digital Global Public Goods. [Online] https://www.researchgate.net/publication/354088457_Digital_Global_Public_Goods [Accessed: 2021-09-13].

Steg, L. et al. 2021 - Steg, L., Perlaviciute, G, Sovacool, B. K., Bonaiuto, M., Diekmann, A., Filippini, M., Hindriks, F., Bergstad, C. J., Matthies, E., Matti, S., Mulder, M., Nilsson, A., Pahl, S., Roggenkamp, M., Schuitema, G., Stern, P.C., Tavoni, M., Thøgersen, J. and Woerdman, E. 2021 A Research Agenda to Better Understand the Human Dimensions of Energy Transitions. Front. Psychol. 12, Article 672776, DOI: 10.3389/fpsyg.2021.672776.

Szalbierz, Z. and RopuszyŃsKa-SuRma, E. 2017. Energy security as a public good. E3S Web of Conferences 14, Article 01005, DOI: 10.1051/e3sconf/20171401005.

Udayasankaran, J.G. et al. 2021 - Udayasankaran, J.G., Kallander, K., Woods, T., Landry, M., Benjamin, P., Harris, L., Nordhaug, L., Fourie, C., Blaschke, S., Grubb, B., Bendor, A. and Downey, M. 2021. Understanding the Relationship between Digital Public Goods and Global Goods in the Context of Digital Health. Digital Public Goods Alliance, Digital Square, UNICEF Health and Information Communication Technology (ICT) Divisions. [Online] https://www.researchgate.net/publication/350959100_Understanding_the_Relationship_between_Digital_Public_Goods_and_Global_ Goods_in_the_Context_of_Digital_Health [Accessed: 2021-09-20].

Wiser, R. and Pickle, S. 1997. Green Marketing, Renewables, and Free Riders: Increasing Customer Demand for a Public Good. [Online] https://www.researchgate.net/publication/252267623_Green Marketing_Renewables_and_Free_Riders_Increasing_Customer_Demand_for_a_Public_Good [Accessed: 2021-09-21].

Yin, Y. et al. 2021 - Yin, Y., Dong, Y., WANG, K., WANG, D. and Jones, B.F. 2021. Science as a Public Good: Public Use and Funding of Science. Proceedings of the 1st Virtual Conference on Implications of Information and Digital Technologies for Development. [Online] https://www.researchgate.net/ publication/351298734_Science_as_a_Public_Good_Public_Use_and_Funding_of_Science/citations [Accessed: 2021-09-20].

Iryna Nyenno, Vyacheslav TrubA, Iryna LomachynsKa, Olena MaZuR

\section{Cyfrowe dobra publiczne jako sposób wspierania niedrogiej i czystej energii}

\section{Streszczenie}

Znaczenie zwiększania poziomu OZE wiąże się z tym, że ich udział w całkowitym wolumenie zużycia energii jest wciąż niewystarczający. Dlatego w niniejszym artykule skupiono się na rozwoju systemu motywacyjnego ukierunkowanego na bardziej aktywne przejście na zużycie ze źródeł odnawialnych w zrównoważonym połączeniu obok źródeł tradycyjnych. Pytanie badawcze brzmi: czy cyfrowe dobra publiczne mogą być środkiem wspierającym korzystanie z „niedrogiej i czystej energii”? Teoretyczne podejście do naszego problemu badawczego to teoria interesariuszy, natomiast koncepcja stosowana do wdrażania me- 
chanizmu motywacji to koncepcja celów zrównoważonego rozwoju Organizacji Narodów Zjednoczonych. Projekt badań jest następujący: badanie rzeczywistych danych dotyczących struktury energetycznej gospodarki światowej; identyfikacja obecnych instrumentów dystrybucji energii odnawialnej; analiza cyfrowych dóbr publicznych jako perspektywicznej formy zachowań związanych ze zrównoważoną energią wprowadzaną w zdigitalizowanym środowisku; definicja interesariuszy z branży energetycznej; opracowanie architektury zużycia energii przez aplikację DPG w celu osiągnięcia celu zrównoważonego rozwoju „niedrogiej i czystej energii”. Główne wnioski z badania są takie, że cyfrowe dobra publiczne zostały uznane za odpowiedni środek motywowania i wspierania zrównoważonych zachowań energetycznych poprzez architekturę zużycia energii, opartą na badaniach i rozwoju, zarządzaniu relacjami z klientami, społecznej odpowiedzialności biznesu - zrównoważony rozwój, realizację techniczną oraz różnorodność tradycyjnych i alternatywnych źródeł energii.

SŁOWA KLUCzOWE: energia, system, cyfrowe dobra publiczne, cel zrównoważonego rozwoju, wartość 